Formatif: Jurnal Ilmiah Pendidikan MIPA

Vol. 8, No. 3, Desember 2018, pp. 211-224

p-ISSN: 2088-351X

e-ISSN: 2502-5457

DOI: http://dx.doi.org/10.30998/formatif.v8i3.2710

\title{
The Development of Engklek Geometry-Learning Media to Preserve Traditional Game
}

\author{
Pengembangan Media Pembelajaran-Engklek Geometri untuk Melestarikan \\ Permainan Tradisonal
}

\author{
Nur Isnaini Utami (*) \\ Universitas Muhammadiyah Surabaya, Jln. Sutorejo No. 59 Surabaya \\ Iis Holisin \\ Universitas Muhammadiyah Surabaya, Jln. Sutorejo No. 59 Surabaya \\ Himmatul Mursyidah \\ Universitas Muhammadiyah Surabaya, Jln. Sutorejo No. 59 Surabaya
}

\begin{abstract}
Received: July 31, 2018

Revised: August 23, 2018

Engklek Geometry is one of mathematics learning media for rectangular material. The purpose of this research is to describe the development

Accepted: September 17, 2018 process of Engklek Geometry learning media to be valid, reliable, and effective. The development model used in this research is the 4-D development model, and the research method is developed with quantitative descriptive approach. Engklek Geometry learning media generated in this development research is valid, reliable, and effective for rectangular material. The value product of Engklek Geometrimathematics learning media is 3.17 , it is"valid" category. Media effectiveness is reviewed from four aspects, namely learning outcomes, student activities, student responses, and teaching ability. The result of this research in class VII C SMP Muhammadiyah 4 Surabaya with classical completion percentage $89,28 \%$, student activity is in the "active" category with percentage $94,95 \%$, student response is "very strong" category with percentage $87,5 \%$, and the value of the teacher's ability is 3.72 classified as "very good" category. While in the second trial in class VII E SMP Muhammadiyah 2 Surabaya obtained the results of learning with a percentage of classical completeness $93.1 \%$, student activity with a percentage of 95.85 is in the "very active" category, student responses obtained percentage $82.07 \%$ "very strong", and the value of the teacher's ability is 3.59 classified as "very good" category.

Keywords: engklek geometri, instructional media, traditional game
\end{abstract}

(*) Corresponding Author: $\quad$ isnaini27011997@gmail.com

How to Cite: Utami, N. I., Holisin, I., \& Mursyidah, H. (2018). The development of engklek geometrylearning media to preserve traditional game. Formatif: Jurnal Ilmiah Pendidikan MIPA, 8 (3): 211-224. http://dx.doi.org/10.30998/formatif.v8i3.2710

\section{PENDAHULUAN}

Arus globalisasi atau semakin pesatnya perkembangan IPTEK di era modern menyebabkan permainan tradisional semakin ditinggalkan dan terpinggirkan dengan munculnya gadget, ataupun teknologi canggih lainnya yang lebih sering dimainkan anak 
bangsa (Saputra, 2017). Salah satu permainan tradisional tersebut adalah permainan engklek. Permainan yang melatih ketangkasan dan keseimbangan kaki ini sebenarnya memiliki berbagai nama, sesuai dengan sebutan di daerah masing-masing. Permainan engklek biasa dimainkan oleh dua sampai enam orang anak (Safitri, 2014). Permainan engklek memiliki beberapa ciri khas. Ciri khas dari permainan ini yaitu berjalan melompat dengan satu kaki (Adpriyadi, 2017).

Cara permainannya, anak mengangkat satu buah kaki dan melompat dengan satu buah kaki satunya di setiap petak pada bidang permainan engklek. Selain itu, terdapat gacu yang dimiliki oleh setiap pemain engklek. Fakta yang terjadi saat ini, sudah jarang ditemukan anak-anak yang bermain permainan tradisional engklek. Padahal permainan tradisional engklek tidak kalah menyenangkan jika bersaing dengan permainan game online, play station, dan permainan lain yang memanfaatkan kecanggihan teknologi. Banyak nilai-nilai kebaikan yang tumbuh dari permainan tradisional engklek, antara lain melatih kemampuan motorik anak, ketangkasan, keseimbangan, menjadikan anak aktif bersosialisasi dengan teman-teman sebaya di lingkungannya, serta meningkatkan rasa kerjasama, kekompakan, dan kebersamaan (Mardayani, Mahardewi, \& Magta, 2016).

Pada Kamis, 2 November 2017, dilakukan penyebaran angket terkait permainan tradisional vs gawai di kelas VII SMP Muhammadiyah 4 Surabaya. Hal ini dilakukan berdasarkan masalah yang didapat saat Praktik Pengalaman Lapangan (PPL) di SMP Muhammadiyah 4 Surabaya pada Tahun Ajaran 2017-2018, banyak siswa kelas VII yang suka bermain gawai pada waktu istirahat. Hasil penyebaran angket ditunjukkan pada Tabel 1.

Tabel 1. Minat Permainan Tradisional VS Gadget

\begin{tabular}{clc}
\hline No. & \multicolumn{1}{c}{ Pernyataan } & Prosentase \\
\hline 1. & $\begin{array}{l}\text { Siswa memiliki dan sering bermain gadget atau smartphone di } \\
\text { rumah. }\end{array}$ & $96,61 \%$ \\
\hline 2. & Siswa memiliki dan sering aktif di akun media sosial. & $97,45 \%$ \\
\hline 3. & Siswa bermain suatu permainan tradisional pada akhir minggu ini. & $16,11 \%$ \\
\hline 4. & $\begin{array}{l}\text { Siswa mengenal dan pernah bermain permainan tradisional } \\
\text { engklek. }\end{array}$ & $65,25 \%$ \\
\hline 5. & $\begin{array}{l}\text { Siswa lebih sering bermain gadget atau smart phone jika } \\
\text { dibandingkan dengan permainan tradisional. }\end{array}$ & $91,52 \%$ \\
\hline
\end{tabular}

Upaya untuk menghidupkan kembali permainan tradisional engklek perlu untuk dilakukan, mengingat banyaknya manfaat yang terkandung pada permainan ini (Yasari, Tegeh, \& Ujianti, 2017). Permainan tradisional dapat digunakan sebagai media pembelajaran dalam menunjang proses pembelajaran (Irwanto, Aspilayani, \& Wahyuddin, 2014). Inovasi yang dikembangkan berupa menerapkan permainan tradisional engklek menjadi suatu media pembelajaran matematika. Gagne (dalam Mudlofir \& Rusydiyah, 2016) mendefinisikan "Media pembelajaran adalah berbagai jenis komponen dalam lingkungan peserta didik yang dapat menumbuhkan sikap belajar." Dengan menggunakan media pembelajaran hasil inovasi dari permainan tradisional engklek, pembelajaran matematika yang biasanya dilakukan di dalam kelas, dimodifikasi dengan belajar dan bermain di luar lingkungan kelas. Selain bermanfaat dalam rangka pengenalan dan pelestarian permainan tradisional engklek, pembelajaran seperti ini akan menciptakan suasana baru yang menyenangkan. 
Kebanyakan siswa menganggap matematika adalah mata pelajaran yang sulit dibandingkan mata pelajaran lainnya (Layn, 2018), sekalipun sebenarnya matematika merupakan pelajaran yang sangat penting serta bertujuan meningkatkan kemampuan berpikir siswa (Leonard \& Linda, 2018). Berdasarkan hasil wawancara langsung dengan guru matematika di kelas VII SMP Muhammadiyah 4 Surabaya, masih terdapat beberapa siswa yang kurang fokus dan aktif dalam proses pembelajaran matematika. Oleh karena itu, subjek pada penelitian ini adalah siswa kelas VII. Selain alasan tersebut, pemilihan subjek ini dilakukan berdasarkan kesesuaian dengan materi pembelajaran yang digunakan dalam proses pengembangan media pembelajaran, yaitu materi geometri di SMP kelas VII. Pembelajaran dengan media permainan tradisional ini diharapkan akan menambah minat siswa dalam mengikuti pembelajaran matematika. Siswa mendapatkan variasi baru dalam pembelajaran sehingga tidak merasa bosan atau jenuh. Kegiatan mengadakan variasi dalam proses pembelajaran memiliki sejumlah manfaat bagi siswa dan kualitas pembelajaran. Edi Soegito, dkk dalam (Barnawi \& Arifin, 2017) mengungkapkan bahwa pengadaan variasi memiliki fungsi atau manfaat untuk, (1) Mengurangi kebosanan siswa dalam mengikuti pelajaran, (2) Meningkatkan motivasi belajar siswa, (3) Memacu, mengembangkan, dan mengikat perhatian siswa pada pelajaran yang sedang mereka ikuti, (4) Menumbuhkan rasa ingin tahu siswa pada hal-hal baru yang sedang dipelajari, (5) Menumbuhkan perilaku belajar positif pada diri siswa, (6) Meningkatkan partisipasi siswa dalam interaksi kegiatan pembelajaran, (7) Memperlancar dan menjelaskan komunikasi antara guru dan siswa. Selain manfaat tersebut, pengembangan suatu media pembelajaran dengan permainan tradisional engklek dapat melatih aspek fisik, motorik, serta kognitif siswa.

Memerhatikan masalah yang ada, dilakukan penelitian pengembangan media pembelajaran matematika engklek geometri sebagai upaya melestarikan permainan tradisional. Bidang permainan tradisional pada engklek geometri dimodifikasi sehingga memiliki beraneka bentuk segiempat. Pengembangan media pembelajaran matematika engklek geometri diterapkan pada siswa kelas VII C SMP Muhammadiyah 4 Surabaya, dan dikembangkan pada skala yang lebih luas yaitu kelas VII E SMP Muhammadiyah 2 Surabaya. Tujuan penelitian ini adalah untuk mendeskripsikan proses pengembangan media pembelajaran matematika engklek geometri yang valid dan reliabel, serta mendeskripsikan efektivitas penggunaan media pembelajaran matematika engklek geometri pada siswa kelas VII.

\section{METODE}

Metode yang digunakan dalam penelitian ini adalah pengembangan media dengan pendekatan deskriptif kuantitatif. Model pengembangan yang digunakan yaitu model pengembangan 4-D yang dikemukakan oleh S. Thiangarajan, Dorothy S. Semmel, dan Melvyn I. Semmel pada tahun 1974. Model pengembangan 4-D terdiri dari 4 tahap yaitu Pendefinisian (Define), Perancangan (Design), Pengembangan (Develop), dan Penyebarluasan (Disseminate) (Al-Tabany, 2017). Model pembelajaran yang digunakan adalah model pembelajaran langsung (Direct Instruction).

Adapun instrumen pengumpulan data yang digunakan dalam penelitian ini yaitu,

1) Lembar Validasi Media Pembelajaran Engklek Geometri

2) Lembar Observasi Kemampuan Guru

3) Lembar Observasi Aktivitas Siswa

4) Tes Hasil Belajar Siswa

5) Angket Respon Siswa 
Tahap pengembangan media pembelajaran matematika Engklek Geometri dipaparkan pada uraian berikut.

1) Tahap Pendefinisian (Define)

Tahap pendefinisian pada penelitian ini meliputi memberikan gambaran tentang bagaimana mendefinisikan serta menetapkan syarat-syarat pembuatan media Engklek Geometri. Langkah yang dilakukan antara lain,

a) Analisis Awal--Akhir

Pada tahap analisis awal-akhir dilakukan telaah terhadap kurikulum dan penggunaan perangkat pembelajaran yang sesuai di sekolah uji coba pertama sehingga tercapai proses pembelajaran yang baik dan optimal.

b) Analisis Siswa

Pada tahap analisis siswa dilakukan telaah karakteristik siswa yang menjadi subjek penelitian, yang mencakup kemampuan fisik, psikis, dan psikomotor siswa, latar belakang siswa, sikap dan respon terhadap materi pembelajaran, usia dan tingkat kedewasaan, motivasi dalam mengikuti pembelajaran, dan lain sebagainya.

c) Analisis Tugas

Pada tahap ini peneliti merumuskan dan menyusun tugas yang diberikan untuk siswa dalam pembelajaran materi segiempat dengan penggunaan media pembelajaran engklek geometri.

d) Analisis Konsep

Pada tahap ini peneliti mengidentifikasi, merumuskan, serta menyusun konsepkonsep utama yang relevan.

e) Perumusan Tujuan Pembelajaran

Pada tahap ini peneliti merumuskan tujuan pembelajaran yang ingin dicapai. Tujuan terfokus pada materi segiempat di kelas VII SMP semester II dengan media pembelajaran engklek geometri.

2) Tahap Perancangan (Design)

Pada tahap perancangan, akan dihasilkan prototipe media pembelajaran engklek geometri dan perangkat pembelajaran. Langkah yang dilakukan pada tahap ini, yaitu

a) Pemilihan Format Pembelajaran

Pada tahap pemilihan format, peneliti melakukan pemilihan format untuk media pembelajaran engklek geometri dan perangkat pembelajaran dengan menggunakan model pembelajaran langsung.

b) Pemilihan Media Pembelajaran

Pemilihan media pembelajaran yang sesuai dengan materi pembelajaran diperlukan agar tercapai tujuan pembelajaran. Media pembelajaran yang digunakan dalam penelitian ini yaitu Permainan Engklek Geometri untuk materi geometri (segiempat) di kelas VII semester II.

c) Penyusunan Tes Pembelajaran

Penyusunan tes pembelajaran ini digunakan untuk mengukur kemampuan serta perubahan tingkah laku pada diri siswa setelah menerima materi pembelajaran.

3) Tahap Pengembangan (Develop)

Tujuan dari tahap pengembangan adalah menghasilkan media pembelajaran engklek geometri dan perangkat pembelajaran yang telah direvisi berdasarkan masukan dari para ahli di bidang pendidikan matematika sehingga diperoleh bentuk akhir media pembelajaran yang valid dan efektif.

Peran validator penting dalam tahap ini. Validator merupakan orang yang menilai kelayakan instrumen dan produk (media) yang dikembangkan dalam penelitian. Validator dapat berupa pakar, ahli, teman sejawat, praktisi, dan yang relevan (Syahmaidi, 2015). Dengan memerhatikan keahlian validator, dipilih dua orang 
sebagai validator pada penelitian ini. Validator pertama adalah dosen Program Studi Pendidikan Matematika Universitas Muhammadiyah Surabaya, yaitu Sandha Soemantri, S.Pd., M.Pd., yang mempunyai keahlian di bidang pengembangan media pembelajaran. Sedangkan validator ke dua adalah guru matematika dari SMP Muhammadiyah 4 Surabaya, Drs. Ali Mujafal, M.Pd.I., selaku praktisi.

Setelah tahap pengembangan, tahapan berikutnya adalah tahap uji coba produk media engklek geometri. Uji coba pertama dilaksanakan di kelas VII C SMP Muhammadiyah 4 Surabaya, yang berlokasi di Jl. Gadung III No. 7 Kecamatan Wonokromo, Surabaya pada tanggal 21 Februari 2018 sampai 28 Februari 2018. Uji coba kedua dilaksanakan di kelas VII E SMP Muhammadiyah 2 Surabaya yang berlokasi Jalan Genteng Muhammadiyah No.28, Surabaya pada tanggal 15 Maret 2018 sampai 29 Maret 2018.

\section{HASIL DAN PEMBAHASAN}

\section{Hasil}

Berdasarkan metode yang telah digunakan, penelitian ini memperoleh hasil sebagai berikut:

1. Tahap Pendefinisian (Define)

a. Analisis Awal--Akhir

Pada tanggal 21 Februari 2018, dilakukan pengamatan dan wawancara di kelas VII C SMP Muhammadiyah 4 Surabaya terkait proses pembelajaran matematika. Hasil dari kegiatan tersebut meliputi,

1) Kurikulum yang digunakan adalah kurikulum 2013.

2) Proses pembelajaran matematika masih didominasi oleh guru. Keaktifan dan partisipasi siswa pada proses pembelajaran masih belum optimal.

3) Media pembelajaran pendukung yang digunakan selama ini hanya LCD dan papan tulis. Guru belum pernah menerapkan media pembelajaran khusus untuk mendukung proses pembelajaran matematika, sehingga masih ada siswa yang kurang memerhatikan serta memahami materi yang disampaikan guru.

b. Analisis Siswa

Hasil yang diperoleh dari telaah karakteristik siswa kelas VII C SMP Muhammadiyah 4 Surabaya sebagai berikut,

1) Kemampuan fisik, psikis, dan psikomotor siswa termasuk dalam kategori baik.

2) Latar belakang siswa terhadap materi pembelajaran yang akan disampaikan pada penelitian ini sudah sesuai, sebab siswa sudah pernah memperoleh materi segiempat pada jenjang SD.

3) Sikap dan respon siswa terhadap materi pembelajaran sebelum segiempat dan pada saat materi segiempat termasuk kategori baik. Berdasarkan pengamatan, ada $72 \%$ siswa yang aktif dalam proses pembelajaran. Sisanya, siswa pasif dan kurang fokus mengikuti proses pembelajaran.

4) Rata-rata usia siswa adalah 12 sampai 13 tahun, sesuai dengan standar usia untuk siswa kelas VII tahun ajaran 2017/2018.

5) Motivasi siswa dalam mengikuti pembelajaran matematika sudah cukup baik. Semua siswa mengikuti pembelajaran dengan baik sesuai arahan dan bimbingan dari guru. 
Formatif: Jurnal Ilmiah Pendidikan MIPA

Vol. 8, No. 3, Desember 2018, pp. 211-224

p-ISSN: 2088-351X

e-ISSN: 2502-5457

DOI: http://dx.doi.org/10.30998/formatif.v8i3.2710

c. Analisis Tugas

Tugas yang diberikan pada siswa sesuai dengan indikator pencapaian kompetensi pada penelitian ini.

1) Pertemuan I

Siswa mengerjakan Lembar Kerja Siswa (LKS) yang diberikan secara berkelompok untuk menemukan sifat, pengertian, serta menemukan dan menghitung luas, keliling dari bangun datar segiempat (persegi, persegi panjang, jajar genjang, belah ketupat, layang-layang, dan trapesium).

2) Pertemuan II

Siswa melakukan uji coba bermain dengan menggunakan media pembelajaran Engklek Geometri dalam kelompok. Apabila siswa berhasil menyelesaikan permainan media pembelajaran Engklek Geometri sesuai aturan, siswa tersebut akan memperoleh kartu soal yang harus dia kerjakan pada lembar jawaban yang telah disediakan.

Pada akhir pembelajaran, siswa diberikan lembar tes akhir materi Segiempat untuk dikerjakan sebagai evaluasi hasil belajar siswa.

d. Analisis Konsep

Konsep yang diidentifikasi, dirumuskan, serta disusun pada langkah ini adalah konsep yang relevan dengan materi segiempat (persegi, persegi panjang, jajar genjang, belah ketupat, layang-layang, dan trapesium).

e. Perumusan Tujuan Pembelajaran

Tujuan pembelajaran yang ingin dicapai pada materi segiempat melalui permainan dengan menggunakan media Engklek Geometri, diharapkan siswa dapat,

1) Mendefinisikan dan menjelaskan sifat-sifat bangun datar segiempat (persegi, persegi panjang, belah ketupat, jajar genjang, trapesium, dan layang-layang).

2) Mendefinisikan dan menjelaskan pengertian segiempat (persegi, persegi panjang, belah ketupat, jajar genjang, trapesium, dan layang-layang).

3) Menemukan serta menghitung luas segiempat (persegi, persegi panjang, belah ketupat, jajar genjang, trapesium, dan layang-layang).

4) Menemukan serta menghitung keliling segiempat (persegi, persegi panjang, belah ketupat, jajar genjang, trapesium, dan layang-layang).

2. Tahap Perancangan (Design)

Pada tahap ini dihasilkan prototipe media pembelajaran matematika yaitu Engklek Geometri, serta perangkat pembelajaran pendukungnya yang meliputi RPP, LKS, Lembar Tes Akhir, dan sebagainya.

a. Pemilihan Format Pembelajaran

Format media pembelajaran dan perangkat pembelajaran yang digunakan disesuaikan dengan model pembelajaran yang digunakan yaitu Model Pembelajaran Langsung.

b. Pemilihan Media Pembelajaran

Media pembelajaran Engklek Geometri yang akan dikembangkan disesuaikan dengan materi pembelajaran segiempat.

c. Penyusunan Tes Pembelajaran

Tes pembelajaran yang digunakan dalam penelitian ini berupa lembar tes akhir yang dikerjakan oleh siswa pada akhir pembelajaran.

3. Tahap Pengembangan (Develop)

a. Validasi Para Ahli

Perangkat pembelajaran yang divalidasi para ahli antara lain,

1) Media pembelajaran matematika engklek geometri. 
2) Kartu soal pada media pembelajaran matematika engklek geometri.

3) Soal pada kartu soal media pembelajaran matematika engklek geometri.

4) Rencana Pelaksanaan Pembelajaran (RPP).

5) Lembar Kerja Siswa (LKS).

6) Lembar tes hasil belajar siswa.

7) Lembar observasi guru dalam mengelola pembelajaran.

8) Lembar observasi aktivitas siswa dalam pembelajaran.

9) Lembar angket respon siswa.

Aspek yang dinilai untuk instrumen penelitian tersebut memiliki skala penilaian sebagai berikut, 1 (tidak baik atau tidak valid), 2 (kurang baik atau kurang valid), 3 (baik atau cukup valid), 4 (sangat baik atau valid) (Uyun, Holisin, \& Kristanti, 2017). Hasil validasi dari perangkat pembelajaran diberikan pada uraian berikut,

1) Hasil validasi media pembelajaran matematika Engklek Geometri dari kedua validator diperoleh rata-rata total sebesar 3.17, yang tergolong valid.

2) Rata-rata total untuk ketiga aspek penilaian kartu soal media pembelajaran Engklek Geometri yaitu 3.28, termasuk kategori valid.

3) Nilai kevalidan soal dalam kartu soal media Engklek Geometri memiliki ratarata total 3.17. Sehingga kartu soal media pembelajaran Engklek Geometri termasuk pada kategori valid, dan dapat digunakan.

4) Hasil validasi RPP pada materi segiempat untuk pertemuan 1 dan 2 dari para validator diperoleh rata-rata total dari ketiga aspek penilaian RPP yaitu 3.52, yang tergolong kategori valid.

5) Hasil validasi LKS diperoleh rata-rata total 3.61. Berdasarkan kriteria kevalidan media dan perangkat pembelajaran, LKS ini termasuk kategori valid.

6) Rata-rata total nilai lembar tes hasil belaja rsiswa dinilai dari tiga aspek sebesar 3.67. Berdasarkan kriteria kevalidan media dan perangkat pembelajaran, lembar tes hasil belajar siswa ini tergolong kategori valid.

7) Hasil validasi lembar observasi aktivitas guru dalam mengelola pembelajaran sebesar 3.36. Jadi, lembar observasi guru ini termasuk dalam kategori valid.

8) Lembar observasi aktivitas siswa memiliki rata-rata total kevalidan sebesar 3.39. Lembar observasi aktivitas siswa ini termasuk kategori valid.

9) Hasil validasi lembar angket respon siswa memilikirata-rata total 3.22, yang tergolong dalam kategori valid.

b. Uji Validitas dan Reliabilitas Butir Soal Tes Hasil Belajar

Setelah melakukan uji validitas media dan perangkat pembelajaran, dilakukan uji coba awal di kelas VII C SMP Muhammadiyah 4 Surabaya. Dari uji coba awal, diperoleh hasil:

1) Uji Validitas Butir Soal

Hasil uji validitas butir soal ditunjukkan dalam Tabel 2.

Tabel 2. Uji Validitas Butir Soal Tes Hasil Belajar

\begin{tabular}{ccc}
\hline Butir Nomor & Koefisien Korelasi & Interprestasi \\
\hline 1 & 0,43 & Validitas sedang \\
\hline 2 & 0,64 & Validitas tinggi \\
\hline 3 & 0,62 & Validitas tinggi \\
\hline 4 & 0,69 & Validitas tinggi \\
\hline 5 & 0,59 & Validitas sedang \\
\hline 6 & 0,74 & Validitas tinggi \\
\hline
\end{tabular}


Formatif: Jurnal Ilmiah Pendidikan MIPA

Vol. 8, No. 3, Desember 2018, pp. 211-224

p-ISSN: 2088-351X

e-ISSN: 2502-5457

DOI: http://dx.doi.org/10.30998/formatif.v8i3.2710

2) Uji Reliabilitas Soal

Pada uji reliabilitas dengan menggunakan rumus reliabilitas

$$
r_{11}=\left(\frac{n}{n-1}\right)\left(1-\frac{\sum{\sigma_{i}}^{2}}{\sigma_{t}{ }^{2}}\right)
$$

(Yulvinamaesari \& Tenriawaru, 2017)

Keterangan:

$r_{11}=$ reliabilitas istrument

$n$ =banyakanya butir pertanyaan atau banyaknya soal

$\sigma_{i}^{2}=$ varians butir atau skor tiap-tiap item

$\sigma_{t}{ }^{2}=$ varians soal

diperoleh reliabilitas 0,85 dengan kriteria reliabilitas tinggi.

c. Uji Coba Awal (produk pertama)

Uji coba awal pengembangan media pembelajaran matematika Engklek Geometri

dilakukan di kelas VII C SMP Muhammadiyah 4 Surabaya.

1) Hasil Pengembangan

Hasil keefektifan media Engklek Geometri dan perangkat pembelajaran ditinjau dari empat aspek efektivitas yaitu,

a) Aktivitas Siswa dalam Pembelajaran

Presentase aktivita siswa pada pertemuan I adalah 95,2 termasuk kategori "sangat aktif". Presentase aktivitas siswa pada pertemuan II sebesar 94,7\% termasuk dalam kategori "aktif".

b) Aktivitas Guru dalam Mengelola Pembelajaran

Berdasarkan hasil pengamatan kepada guru di pertemuan I dan II, diperoleh rata rata total kemampuan guru dalam mengelola pembelajaran sesuai Tabel 3.

Tabel 3. Rata-Rata Observasi Kemampuan Guru

\begin{tabular}{cc}
\hline Pertemuan & Rata-rata \\
\hline 1 & 3,75 \\
\hline 2 & 3,69 \\
\hline Rata-rata Total & 3,72 \\
\hline
\end{tabular}

Dari Tabel 3, rata-rata total kemampuan guru dalam mengelola pembelajaran materi segiempat untuk pertemuan I dan II yaitu 3.72, yang termasuk dalam kategori sangat baik.

c) Hasil Belajar Siswa

Siswa dikatakan tuntas secara individual apabila telah memenuhi Kriteria Ketuntasan Minimal (KKM) mata pelajaran matematika yang ditetapkan di SMP Muhammadiyah 4 Surabaya, yaitu 75. Jumlah siswa kelas VII C yang tuntas 25 siswa, dan 3 siswa tidak tuntas. Nilai rata-rata kelas VII C yaitu 84,57 , sedangkan perhitungan persentase ketuntasan klasikal diperoleh $89,28 \%$.

d) Respon Siswa

Respon siswa adalah tanggapan dari siswa terhadap pembelajaran yang telah dilaksanakan, dari adanya penggunaan media pembelajaran (Yaumi, 2013). Rata-rata total respon siswa yaitu $87,5 \%$. Berdasarkan kriteria persentase 
Formatif: Jurnal Ilmiah Pendidikan MIPA

Vol. 8, No. 3, Desember 2018, pp. 211-224

p-ISSN: 2088-351X

e-ISSN: 2502-5457

DOI: http://dx.doi.org/10.30998/formatif.v8i3.2710

nilai respon siswa, persentase tersebut termasuk kategori sangat kuat dan dapat disimpulkan bahwa respon siswa positif.

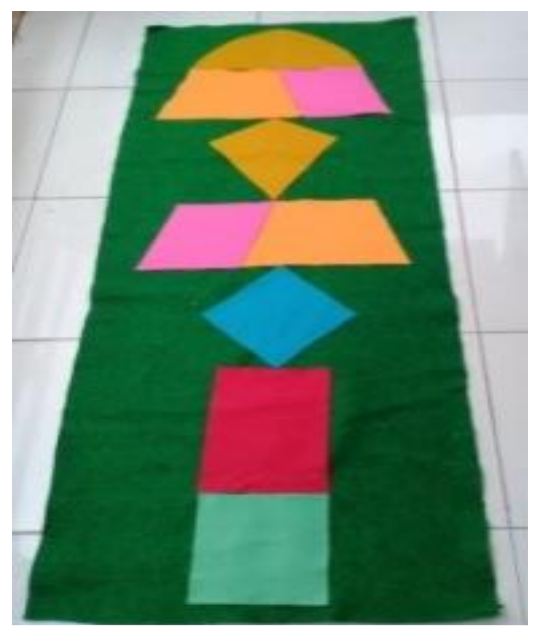

Gambar 1. Bidang Permainan Engklek Geometri Sebelum Revisi

2) Revisi Produk

Berdasarkan hasil penilaian validator dan hasil pengembangan uji coba awal media Engklek Geometri di kelas VII C SMP Muhammadiyah 4 Surabaya pada materi Segiempat, media ini dinyatakan valid dan efektif. Akan tetapi, masih terdapat beberapa hal yang perlu direvisi. Revisi bidang permainan media Engklek Geometri meliputi mengganti warna dari petak berbentuk layanglayang, dan memberi judul media pada bagian atas bidang. Pengubahan warna petak berbentuk layang-layang dilakukan supaya tidak sama dengan warna petak setengah lingkaran, sehingga siswa tidak merasa bingung saat memainkannya. Meskipun petak setengah lingkaran bukan bidang segiempat. Namun tidak dihilangkan karena merupakan ciri dari engklek atau tapak gunung. Sedangkan pemberian judul media dan tanda start dilakukan supaya siswa maupun guru mengetahui nama media, letak bagian atas dan bawah media, serta posisi awal permainan.

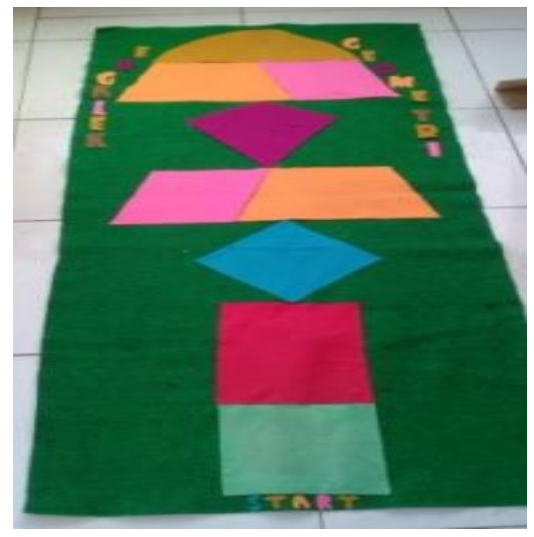

Gambar 2. Bidang Permainan Engklek Geometri Setelah Revisi 
Formatif: Jurnal Ilmiah Pendidikan MIPA

Vol. 8, No. 3, Desember 2018, pp. 211-224

p-ISSN: 2088-351X

e-ISSN: 2502-5457

DOI: http://dx.doi.org/10.30998/formatif.v8i3.2710

Media Engklek Geometri sebelum revisi diberikan pada Gambar 1. Adapun Gambaran media pembelajaran matematika yang telah direvisi diberikan pada Gambar 2.

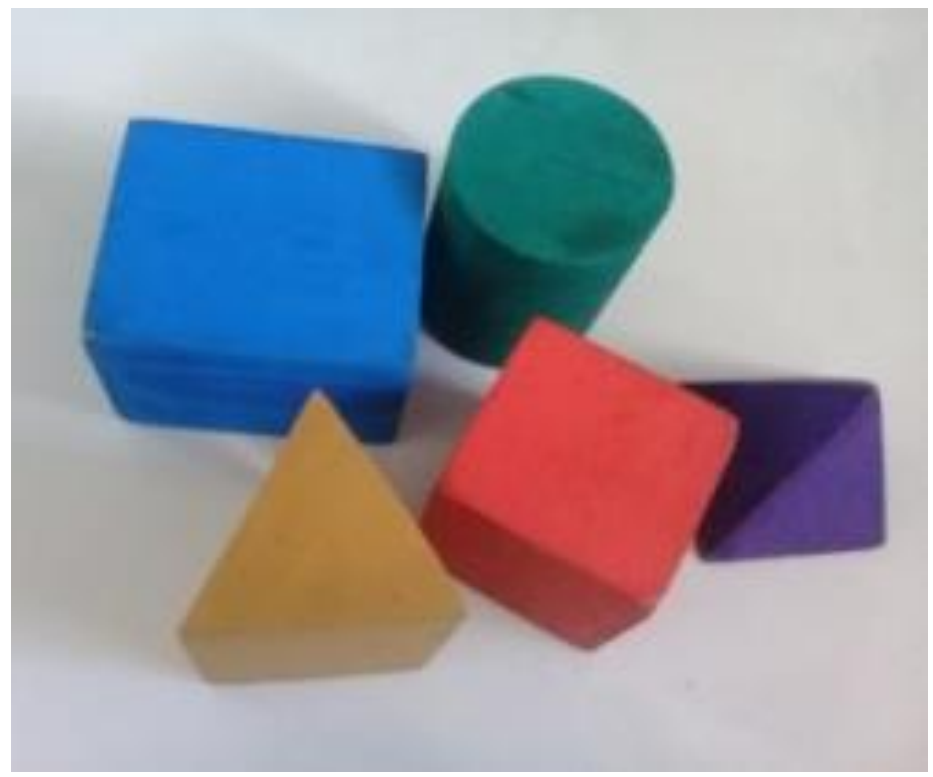

Gambar 3. Gacu Media Engklek Geometri

Selain bidang permainan, media engklek geometri juga terdiri dari gacu dan kartu soal. Revisi untuk gacu, gacu dibuat agak pipih sehingga mempermudah siswa dalam melempar. Untuk kartu soal, baik hasil penilaian validator dan hasil pengembangan uji coba awal tidak terdapat saran perbaikan.

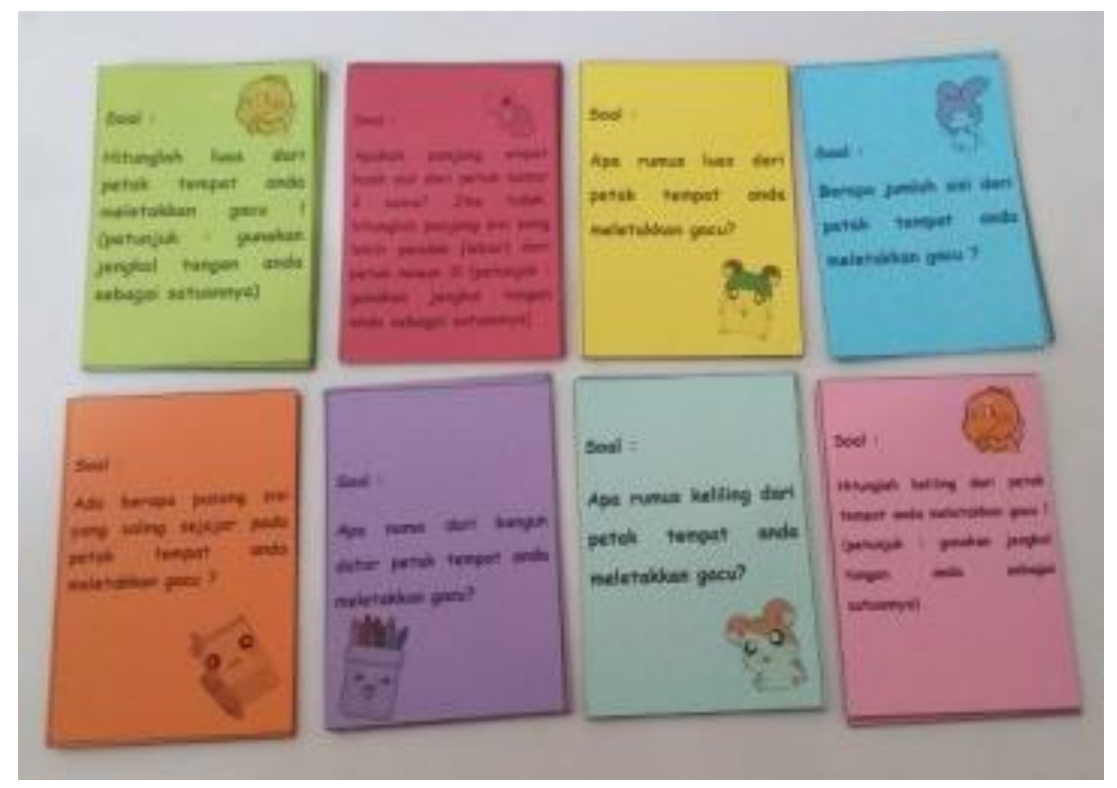

Gambar 4. Kartu Soal Media Engklek Geometri 


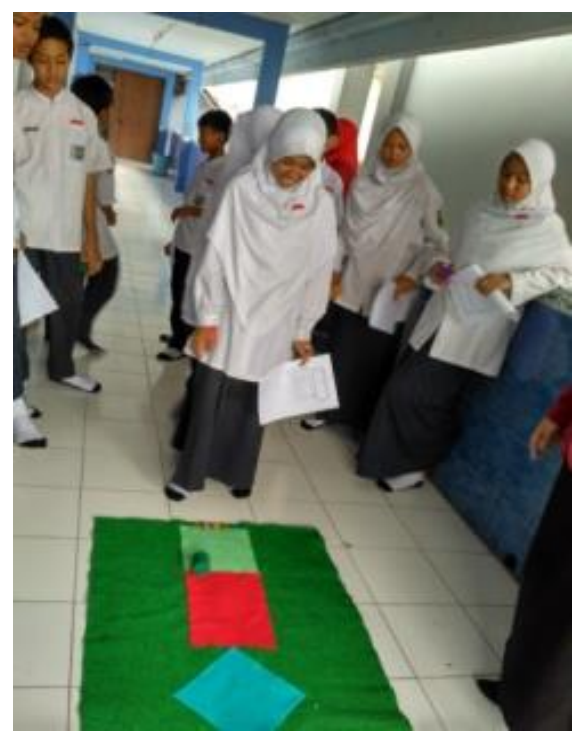

Gambar 5. Aktivitas Siswa Kelas VII C SMPM 4 Surabaya Bermain Media Pembelajaran Matematika Engklek Geometri

\section{d. Uji Coba Produk Kedua}

Langkah selanjutnya setelah uji coba produk pertama adalah uji coba produk kedua. Uji coba kedua media Engklek Geometri dilaksanakan di kelas VII E SMP Muhammadiyah 2 Surabaya. Hasil pengembangan media ini sebagai berikut,

1) Hasil Pengembangan

Hasil pengembangan media pembelajaran matematika Engklek Geometri ditinjau dari empat aspek keefektifan yaitu sebagai berikut,

a) Aktivitas Siswa dalam Pembelajaran

presentase aktivitas siswa pertemuan I yaitu 96\%. Aktivitas siswa pada pertemuan I ini termasuk kategori "sangat aktif". Presentase aktivitas siswa untuk pertemuan II, yaitu 95,7\%. Aktivitas siswa pada pertemuan II ini termasuk dalam kategori "sangat aktif".

b) Kemampuan dan Aktivitas Guru dalam Mengelola Pembelajaran

Rata-rata total kemampuan guru dalam mengelola pembelajaran materi segiempat untuk pertemuan I dan II adalah 3,59. Berdasarkan kriteria kemampuan guru dalam mengelola pembelajaran, dapat disimpulkan kemampuan guru dalam mengelola pembelajaran termasuk kategori sangat baik.

c) Tes Hasil Belajar Siswa

Siswa dikatakan tuntas secara individual apabila telah memenuhi Kriteria Ketuntasan Minimal (KKM) mata pelajaran Matematika yang ditetapkan di SMP Muhammadiyah 2 Surabaya yaitu 75. Jumlah siswa kelas VII E SMP Muhammadiyah Surabaya adalah 29 siswa. Banyak siswa kelas VII E yang tuntas ada 26 siswa, dan yang tidak tuntas adalah 2 siswa. Nilai rata-rata kelas VII E yaitu 86,03, sedangkan perhitungan persentase ketuntasan secara klasikal diperoleh hasil 93,1\%.

d) Respon Siswa

Hasil respon siswa kelas VII E SMP Muhammadiyah 2 Surabaya berdasarkan kelima butir pertanyaan pada angket respon yang diberikan 
Formatif: Jurnal Ilmiah Pendidikan MIPA

Vol. 8, No. 3, Desember 2018, pp. 211-224

p-ISSN: 2088-351X

e-ISSN: 2502-5457

DOI: http://dx.doi.org/10.30998/formatif.v8i3.2710

memiliki rata-rata total yaitu $82,07 \%$. Persentase nilai respon siswa kelas VII E SMP Muhammadiyah 2 Surabaya termasuk dalam kategori sangat kuat, dan dapat disimpulkan bahwa respon siswa positif.

2) Revisi Produk

Media pembelajaran matematika Engklek Geometri yang dikembangkan pada uji coba kedua di kelas VII E SMP Muhammadiyah 2 Surabaya berdasarkan hasil pengembangan, termasuk dalam kategori valid dan efektif untuk digunakan. Dalam prosesnya, siswa dapat memainkan media tanpa banyak bertanya. Setelah guru menjelaskan secara detail mengenai media engklek geometri serta aturan permainan, siswa dan guru menuju ke lapangan untuk bermain media engklek geometri. Siswa bermain engklek geometri sesuai dengan kelompok yang telah ditentukan. Mereka antusias dalam mengikuti permainan media engklek geometri.

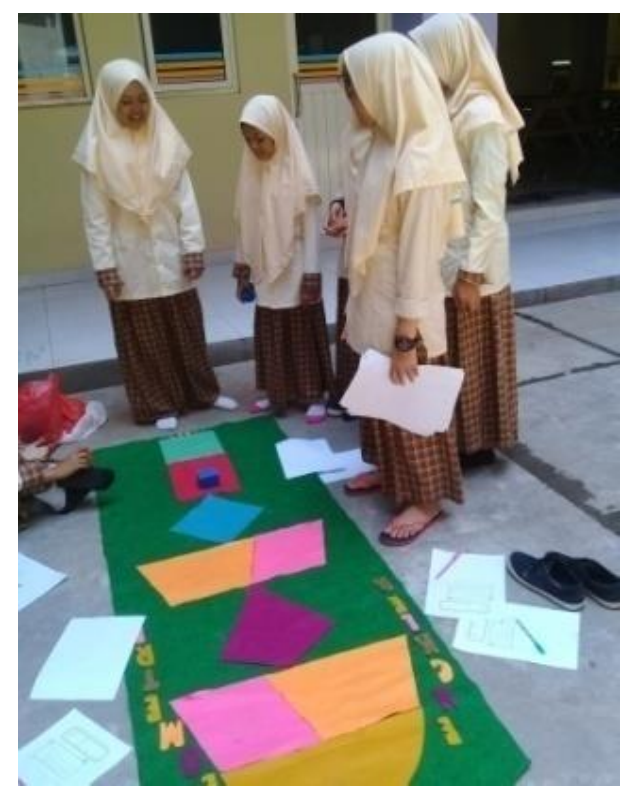

Gambar 6. Aktivitas Siswa Kelas VII E SMP Muhammadiyah 2 Surabaya Bermain Media Pembelajaran Matematika Engklek Geometri

\section{Pembahasan}

Berdasarkan keseluruhan proses, didapatkan media Engklek Geometri yang valid dan reliable untuk digunakan dalam proses pembelajaran matematika materi segiempat. Media Engklek Geometri ini terdiri dari bidang permainan, gacu, kartu soal, dan lembar jawaban. Setelah melakukan pengembangan media pembelajaran matematika Engklek Geometri di SMP Muhammadiyah 4 Surabaya dan SMP Muhammadiyah 2 Surabaya, dilakukan evaluasi kelebihan dan kekurangan media pembelajaran matematika menurut fakta dilapangan.

Kelebihan media pembelajaran matematika Engklek Geometri antara lain,

1. Media pembelajaran matematika Engklek Geometri dapat menambah keaktifan siswa dalam mengikuti pembelajaran matematika, khususnya materi Segiempat.

2. Pengembangan media pembelajaran matematika Engklek Geometri dapat menjadi pengalaman baru bagi siswa melakukan pembelajaran di luar ruangan kelas. 
3. Adanya pengembangan media pembelajaran matematika Engklek Geometri ini sekaligus menjadi upaya pelestarian permainan tradisional Engklek yang mulai terpinggirkan jaman.

4. Media pembelajaran matematika Engklek Geometri dapat menambah variasi media pembelajaran matematika yang digunakan oleh guru untuk mendukung proses pembelajaran matematika. adalah,

Sedangkan kekurangan Media Pembelajaran Matematika Engklek Geometri ini

1. Media pembelajaran matematika Engklek Geometri terbatas untuk materi terkait geometri, contohnya materi pembelajaran yang digunakan pada penelitian ini yaitu materi Segiempat.

2. Permainan engklek merupakan permainan outdoor atau permainan yang dilakukan di luar ruangan (Desvarosa, 2016). Pengembangan media pembelajaran matematika Engklek Geometri sebaiknya dilakukan di luar ruangan kelas contohnya di lapangan, aula, atau hall. Jadi, sekolah yang cocok digunakan untuk pengembangan media ini adalah sekolah yang memiliki lapangan, aula, atau hall.

\section{PENUTUP}

Penelitian pengembangan ini telah menghasilkan media pembelajaran matematika Engklek Geometri, beserta dengan perangkat pembelajarannya. Subjek uji coba penelitian pengembangan ini adalah kelas VII C SMP Muhammadiyah 4 Surabaya dan kelas VII E SMP Muhammadiyah 2 Surabaya. Simpulan dari hasil penelitian pengembangan media pembelajaran matematika engklek geometri yang dihasilkan dalam penelitian pengembangan ini tergolong valid, reliabel, dan efektif untuk materi segiempat. Kevalidan produk media pembelajaran matematika engklek geometri yaitu 3,17, termasuk kategori "valid". Keefektifan media ditinjau dari empat aspek, yaitu hasil belajar, aktivitas siswa, respon siswa, dan kemampuan guru. Hasil belajar siswa kelas VII C SMP Muhammadiyah 4 Surabaya dengan persentase ketuntasan klasikal $89,28 \%$, aktivitas siswa yang termasuk kategori "aktif" dengan persentase $94,95 \%$, respon siswa termasuk kategori "sangat kuat" dengan persentase 87,5\%, dan diperoleh nilai kemampuan guru yaitu 3,72 tergolong kategori "sangat baik". Sedangkan pada uji coba kedua di VII E SMP Muhammadiyah 2 Surabaya diperoleh hasil belajar dengan persentase ketuntasan secara klasikal 93,1\%, aktivitas siswa dengan persentase 95,85 yang termasuk kategori "sangat aktif", respon siswa diperoleh persentase $82,07 \%$ dengan kategori "sangat kuat", dan nilai kemampuan guru yaitu 3,59 yang termasuk kategori "sangat baik".

\section{DAFTAR PUSTAKA}

Adpriyadi (2017). Permainan tradisional engklek untuk meningkatkan kemampuan motorik kasar kelompok B. Jurnal Pendidikan dan Pemberdayaan Masyarakat, 4(2), 187-198.

Al-Tabany, T. I. (2017). Mendesain Model Pembelajaran: Inovatif, Progresif, dan Kontekstual. (T. T. Tutik, Penyunt.) Jakarta: Kencana. 
Barnawi, \& Arifin, M. (2017). Microteaching: Teori \& Praktik Pengajaran yang Efektif dan Kreatif. Jogjakarta: Ar-Ruzz Media.

Desvarosa, E. (2016). Penerapan permainan tradisional engklek dalam meningkatkan kemampuan kognitif anak usia 5-6 tahun di TK Bina Guna. Jurnal Handayani PGSD FIP UNIMED, 6(1), 109-116.

Irwanto, Aspilayani, \& Wahyuddin. (2014). Implementasi media pembelajaran berbasis permainan tradisional dalam rangka pengembangan pendidikan dan karakter bangsa. Jurnal PENA: Penelitian dan Penalaran, 1(1), 21-30.

Layn, M. R. (2018). Improving mathematics learning outcomes through cooperative learning model type NHT in grade VIII A students MTs Muhammadiyah. Formatif: Jurnal Ilmiah Pendidikan MIPA, 8(1), 43-50. DOI: http://dx.doi.org/10.30998/formatif.v8i1.2319

Leonard, L., \& Linda, N. N. (2018). Pengaruh kecerdasan logis-matematis dan kecerdasan musikal terhadap higher order thinking skills (HOTS). KALAMATIKA Jurnal Pendidikan Matematika, 3(2), 193-208. http://doi.org/http://dx.doi.org/10.22236/KALAMATIKA.vol3no2.2018pp193208

Mardayani, K. T., Mahardewi, L. P., \& Magta, M. (2016). Penerapan permainan tradisional engklek untuk meningkatkan kemampuan motorik kasar kelompok B di PAUD WIDHYA LAKSMI Singaraja Tahun Ajaran 2015/2016. Jurnal Pendidikan Anak Usia Dini Undiksha, 4(3).

Mudlofir, A., \& Rusydiyah, E. F. (2016). Desain Pembelajaran Inovatif: dari Teori ke Praktik. Jakarta: PT Rajagrafindo Persada.

Safitri, W. (2014, Desember 11). Permainan Tradisional Engklek. Dipetik Desember 26, 2017, dari Permainan Tradisional Indonesia: https://www.permainantradisional.com/2014/12/permainan-tradisional-engklek.html

Saputra, S. Y. (2017). Permainan tradisional vs permainan modern dalam penanaman nilai karakter di sekolah dasar. ELSE (Elementary School Education Journal): Jurnal Pendidikan dan Pembelajaran Sekolah Dasar, 1 (1), 85-94.

Syahmaidi, E. (2015). Pengembangan media e-learning mata pelajaran teknologi informasi dan komunikasi untuk kelas XI SMA. Jurnal Ipteks Terapan : research of applied science and education, 9(1), 88-97. DOI: http://dx.doi.org/10.22216/jit.2015.v9i1.40

Uyun, Q., Holisin, I., \& Kristanti, F. (2017). Pengembangan media handout segitiga dengan model problem based instruction. MUST: Journal of Mathematics Education, Science and Technology, 2(1), 115-128.

Yasari, K. M., Tegeh, I. M., \& Ujianti, P. R. (2017). Pengaruh permainan tradisional engklek terhadap kemampuan anak dalam mengenal angka pada kelompok B di TK Bayu Kumadhala Bubunan. Jurnal Pendidikan Anak Usia Dini Undiksha, 5(2), 1-10.

Yaumi, M. (2013). Prinsip-Prinsip Desain Pembelajaran Disesuaikan dengan Kurikulum 2013. (D. Sidik, \& N. Ibrahim, Penyunt.) Jakarta: Kencana Prenadamedia Group.

Yulvinamaesari, \& Tenriawaru, E. P. (2017). Analisis kemampuan berpikir kreatif mahasiswa fisika. Dinamika, 8(1), 41-55. 